\title{
RESIDUAL GLYCEROL FROM BIODIESEL MANUFACTURING, WASTE OR POTENTIAL SOURCE OF BIOENERGY: A REVIEW
}

\author{
Claudia Santibáñez ${ }^{*}$, María Teresa Varnero², and Mauricio Bustamante ${ }^{3}$
}

This review provides a summary of the research conducted on the use of crude glycerol, the major byproduct of the biodiesel industry, as substrate for anaerobic co-digestion and production of biogas. In general, for every $100 \mathrm{~kg}$ biodiesel produced, approximately $10 \mathrm{~kg}$ crude glycerol is generated. Because this glycerol is expensive to purify for use in food, pharmaceutical, or cosmetic industries, biodiesel producers must seek alternative methods for its disposal. Several studies have demonstrated that the use of crude glycerol as a $\mathrm{C}$ source for fermentation and biogas generation is a promising alternative use for this waste material. The high $\mathrm{C}$ content of glycerol increases the $\mathrm{C}: \mathrm{N}$ ratio in the mixture, avoiding the inhibition of the process by the excess of $\mathrm{N}$ increasing methane production of digesters by 50 to $200 \%$. Anaerobic codigestion of glycerol and a variety of residual biomasses may be a good integrated solution for managing these wastes and simultaneously producing a source of bioenergy in an environmentally friendly way. On the other hand, after anaerobic treatment of glycerol, an organic matter-rich solid waste is generated (digestate). The incorporation of digestates from glycerol co-digestion to soils constitutes an important source of organic matter and nutrients for plants. However, the potential of digestates as an organic soil amendment has not been sufficiently studied. The utilization of glycerol as a potential source of energy, rather than as a waste, seems to be a convenient way of lowering the costs of biodiesel production and making this emerging industry more competitive.

Key words: Anaerobic co-digestion, glycerol, biogas, biodiesel, digestate.

$\mathrm{T}_{\mathrm{o}}^{\mathrm{h}}$ scarcity of fossil fuels, growing emissions combustion-generated pollutants, and their increasing costs, have made alternative fuel sources more attractive. Biodiesel (fatty acid methyl esters) produced by the process of transesterification of vegetable oils or animal fats with methanol are potential substitutes for petroleum-based diesel fuels. Compared to conventional diesel, biodiesel has the advantages of being biodegradable, renewable, non-toxic, and has low pollutant emissions (especially SOx) (Chen et al., 2007). In process of biodiesel production, a heavier separate liquid phase is formed, termed the glycerol phase. The glycerol portion represents approximately 16 to $18 \%$ of the weight of the input of the oil/fat, and its composition is not stabilized. Glycerol is generated as a by-product, not only when biodiesel fuels are produced chemically, but also when they are manufactured enzymatically (Du et al., 2003) and during the production of bioethanol (Yazdani and Gonzalez, 2007).

The dramatic growth of the biodiesel industry has

${ }^{1}$ Universidad Mayor, Facultad de Ciencias Silvoagropecuarias, Camino La Pirámide 5750, Huechuraba, Santiago, Chile. *Corresponding author (claudia.santibanez@umayor.cl).

${ }^{2}$ Universidad de Chile, Facultad de Ciencias Agronómicas, Santa Rosa 11.315, La Pintana, Santiago, Chile.

${ }^{3}$ Universidad Mayor, Facultad de Ingeniería, Av. Manuel Montt 367, Providencia, Santiago, Chile.

Received: 31 March 2011.

Accepted: 10 August 2011. created a surplus of glycerol that has resulted in a dramatic 10-fold decrease in crude glycerol prices in recent years and has generated environmental concerns associated with contaminated glycerol disposal (Yazdani and Gonzalez, 2007). Anaerobic digestion is an attractive waste treatment practice in which both pollution control and energy recovery can be achieved. Many agricultural and industrial wastes are ideal candidates for anaerobic digestion because they contain high levels of easily biodegradable materials (Chen et al., 2008). The main objective of this review is to discuss the progress and research findings on the potential use of residual glycerol from the biodiesel industry as a source for biogas generation. Additionally, we evaluate the potential agricultural applications of digestates obtained as byproducts of anaerobic digestion processes of residual glycerol.

\section{Characteristics of crude glycerol}

The production of biodiesel provides a relatively large amount of co-products and wastes, such as gluten meal, gluten feed, oilcake, wastewater, and crude glycerol (Schievano et al., 2009). Within these wastes, crude glycerol is the major byproduct of the biodiesel industry. In general, about $10 \mathrm{~kg}$ crude glycerol is produced for every $100 \mathrm{~kg}$ of biodiesel. Crude glycerol generated by homogeneous base-catalyzed transesterification contains approximately 50 to $60 \%$ of glycerol, 12 to $16 \%$ of alkalis, especially in the form of alkali soaps and hydroxides, 15 
to $18 \%$ of methyl esters, 8 to $12 \%$ of methanol, and 2 to $3 \%$ of water. In addition to methanol and soaps, crude glycerol also contains a variety of elements such as $\mathrm{Ca}$, $\mathrm{Mg}$, P, or S, and other components (Thompson and $\mathrm{He}$, 2006; Kocsisová and Cvengos, 2006).

The wide range of the purity values can be attributed to different glycerol purification methods used by biodiesel producers and the different feedstocks used in biodiesel production. For example, Thompson and $\mathrm{He}$ (2006) have characterized the glycerol produced from various biodiesel feedstocks. Their study reported that crude glycerol from any feedstock is generally between 60 and 70\% (wt) glycerol. Mustard seed feedstocks had a lower level (62\%) of glycerol, while soy oil feedstock had $67.8 \%$ glycerol and waste vegetable had the highest level (76.6\%) of glycerol. Crude glycerol contains a variety of elements originating from the primary oil, such as $\mathrm{K}(0$ to $217 \mathrm{ppm}), \mathrm{P}$ (12 to $37 \mathrm{ppm}), \mathrm{S}$ (14 to $128 \mathrm{ppm}$ ), Na (1.06 to 1.40$), \mathrm{C}$ (24 to $37 \%), \mathrm{N}(0.04$ to $0.12 \%)$, and protein $(0.05$ to $0.44 \%)$. Larger quantities of $\mathrm{Na}$ or $\mathrm{K}$ are also present, coming from the catalyst. Considering that the processing technology of biodiesel production affects the characteristics of by-products, the new technologies and modern catalysts can be expected to influence the composition and utilization of crude glycerol. As biodiesel production has increased exponentially, the crude glycerol generated in this process has also been generated in a large quantity and is expected to grow steadily in the future. Therefore, it is presumed that there will be a surplus of glycerol in the world market (Adhikari et al., 2007). Furthermore, the economics of biodiesel might also be influenced by the way glycerol co-products are used (Suppes, 2006).

Despite the wide applications of pure glycerol in pharmaceutical, food, and cosmetic industries, the refining of crude glycerol to a high purity is too expensive, especially for small and medium biodiesel producers (Pachauri and He, 2006). To improve the economic feasibility of the biodiesel industry, alternate ways of using the crude glycerol phase have recently been studied. Possibilities such as combustion, coburning, composting, animal feed, thermochemical conversion, and biological conversion have been applied to crude glycerol processing (Luo et al., 2008; Pyle, 2008; Slinn et al., 2008; Valliyappan et al., 2008; Da Silva et al., 2009; H'ajek and Skopal, 2010; Rahmat et al., 2010). Among these different options, the biological production of methane from crude glycerol by anaerobic digestion has several advantages (Yang et al., 2008; López et al., 2009). Besides the production of methane, the advantages include low nutrient requirements, energy savings, and generation of a stabilized digestate which improves soil quality. Glycerol is a readily digestible substance that can easily be stored over a long period. High energy content in the crude glycerol phase makes it an interesting substrate for anaerobic digestion as well, since it offers high production of biogas in smaller reactor volumes.

A great variety of microorganisms are able to use this substrate as a $\mathrm{C}$ source for growth under anaerobic conditions, such as Citrobacter freundii, Klebsiella pneumoniae, Clostridium pasteurianum, Clostridium butyricum, Enterobacter agglomerans, Enterobacter aerogenes and Lactobacillus reuteri (Solomos et al., 1995; Da Silva et al., 2009). The production of biogas through anaerobic digestion offers significant advantages over other forms of crude glycerol treatment. It requires lower investments and simpler operational conditions compared to more sophisticated preprocessing technologies, which makes it ideal for local applications. Less biomass sludge is produced in comparison to aerobic treatment technologies. The digestate is an improved fertilizer for plants. A source of C neutral energy is produced in the form of biogas.

\section{The anaerobic digestion process}

Anaerobic digestion is a naturally occurring process, by which anaerobic microorganisms convert biodegradable organic matter into biogas in the absence of oxygen. Typically these systems are operated under controlled conditions, however this process is essential to the global $\mathrm{C}$ cycle and can be seen naturally occurring on the earth's surface, for example in marshes, soils, landfills, and in the intestines of animals, in effect, wherever the anaerobic decay of organic materials occurs. This anaerobic digestion process occurs with different groups of bacteria in four steps or reactions (Figure 1).

The various fermentations are carried out by different microorganisms, which naturally produce a number of products. These products accumulate only temporarily because of the synergistic relationship that fermentative organisms have with each other, where the products from one group of organisms serve as the substrates for the next group of organisms in an anaerobic food chain, leading to the eventual production of methane (Gottschalk, 1986).

\section{Anaerobic co-digestion of crude glycerol}

Co-digestion is defined as the anaerobic treatment of a mixture of at least two different waste types with the aim of improving the efficiency of the anaerobic digestion process. Co-digestion of various substrates provides in many cases suitable option for anaerobic processing for various technical reasons. One of the main reasons is the stability of $\mathrm{pH}$ and sufficient buffer capacity. Lack of nutrients or high concentration of inhibitory agents can

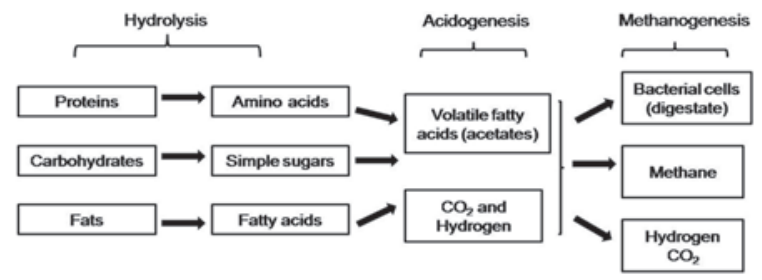

Figure 1. Flow diagram of the anaerobic digestion process. 
also be improved by the sensible choice of co-substrates. A particularly strong reason for co-digestion of feedstock is the adjustment of the $\mathrm{C}: \mathrm{N}$ ratio. Microorganisms generally utilize $\mathrm{C}$ and $\mathrm{N}$ in the ratio of 25 to $30: 1$, but $\mathrm{C}: \mathrm{N}$ ratios can often be considerably lower than this ideal, for example sewage sludge has a $\mathrm{C}: \mathrm{N}$ ratio of approximately 9:1 (Kizılkaya and Bayrakl1, 2005). Feedstocks can vary widely in their $\mathrm{C}: \mathrm{N}$ ratios, and some reactors are affected more than others by non-ideal ratios.

The high organic $\mathrm{C}$ content of glycerol has led to it being used to increase methane production in anaerobic digesters. Several studies have indicated that digestion of recalcitrant substances has been improved by the addition of easily degradable substrates like glycerol (Amon et al., 2006; Ferreira et al., 2007; Soldano et al., 2007; Álvarez et al., 2010). Co-digestion offers several possible ecological, technological and economical advantages because it can improve organic waste treatment through anaerobic digestion. This results not only in stabilization and better nutrient utilization for a variety of agricultural byproducts, but also increases biogas and energy production. Anaerobic co-digestion can increase methane production of digesters by 50 to $200 \%$, depending on the operating conditions and the co-substrates used (Soldano et al., 2007; López et al., 2009; Álvarez et al., 2010). Currently, there is an increasing number of full-scale codigestion plants treating agricultural and industrial organic wastes and there is an increasing interest, mainly in Europe, in using this technology for bioenergy production (Weiland, 2000; Raven and Gregersen, 2007; Álvarez et al., 2010).

On the other hand, it is well known that organic waste anaerobic digestion produces a new semi-liquid waste: digestate, which can be used in agriculture after stabilization or composting. The methane yields from some organic wastes are compared in Table 1, showing that the organic oil wastes that have the highest energy content (Joules) also have the highest methane yields. There are several works that have evaluated the use of glycerol in anaerobic digesters. Mladenovska et al. (2003) found that the mixture of cattle manure with $2 \%$ glycerol significantly increased specific methane yields (224 to 382 $\mathrm{CH}_{4} \mathrm{~g}^{-1}$ volatile solids $\mathrm{d}^{-1}$ ) and a higher removal of organic matter (37 to $51 \%$ ), compared to a digester without the addition of glycerol.
The reactor with mixed waste also exhibited a microbial community with higher densities, and higher numbers of methanogenic microorganisms. Amon et al. (2006) used batch digesters and showed that the addition of glycerin to hog manure in varying amounts resulted in a significant increase in methane production along with a co-fermentation effect. The co-fermentation effects were the highest with glycerin additions of 3 to $6 \%$ to hog manure that had a total solid content of approximately $4 \%$. They also suggested that the addition of glycerol should not exceed $6 \%$ to ensure stable operation. It was noted that at $15 \%$ very high acetic acid concentrations were observed. This was thought to have been caused by loading the sample with too much glycerol and causing a rapid rise in $\mathrm{pH}$, which the methanogens took a long time to adjust to and overcome, hindering methane production. Mackay and Rowlands (2008) considered that it may have been possible to get gain better results at high loading rates if glycerin was increased gradually, allowing the bacteria to acclimatise to it.

The work of Holm-Nielsen et al. (2007) on codigestion of manure with glycerol in semi-continuous lab digesters showed that loading of $3 \%$ (v) glycerol was fairly easy to manage and gave increasing biogas yields. However, when the glycerol concentration exceeded 5 to $7 \mathrm{~g} \mathrm{~L}^{-1}$ in the digester, methane was significantly reduced from organic overloading. This study focused on the addition of varying amounts of glycerol to hog manure in a continuous-feed digester system in an attempt to increase biogas and methane yields. A variety of glycerol-to-manure feeding ratios were investigated in order to determine suitable feeding regimes and evaluate thresholds for $\mathrm{C}$ overloading. Both chemical grade or "pure" glycerol, and crude (unrefined) glycerol (from a biodiesel production process) were tested to asses the impact of impurities in crude glycerol on digestion performance.

A separate study was conducted by Ma et al. (2008) on the co-digestion of potato (Solanum tuberosum L.) processing wastewater and different types of glycerol in a laboratory reactor. It showed the relationship between the purity of the glycerol and the volume of methane produced. Crude, pure and high conductivity (HC) glycerol was used as an additive in the tests. The three

Table 1. Comparison of methane yields of different organic wastes.

\begin{tabular}{llc}
\hline Type of organic waste & \multicolumn{1}{c}{ Composition of waste } & Organic content \\
\hline & & $\%$ \\
Livestock manure & Cellulose, carbohydrates, lipids, proteins & - \\
Pure glycerol & Sugar, alcohol & - \\
Floatation sludge (dewatered) & $65-70 \%$ proteins, 30-35\% lipids & $10-20$ \\
Fish oil sludge & $30-50 \%$ lipids and other organics & 470 \\
Organic household wastes & Carbohydrates, lipids, proteins & $40-18$ \\
Whey & $75-80 \%$ lactose, 20-25\% protein & $40-30$ \\
Soya oil & $90 \%$ vegetable oil & $7-10$ \\
Sewage sludge & Carbohydrates, lipids, proteins & 90 \\
\hline
\end{tabular}

Source: Angelidaki and Ellegaard, 2003. 
glycerol products were digested and monitored via $\mathrm{pH}$, chemical oxygen demand (COD), volatile fatty acids (VFA), and biogas production. These parameters were obtained by standard laboratory procedures and used to find the type of glycerol that produces the largest volume of methane. They reported that supplements of pure glycerol of $2 \mathrm{~mL} \mathrm{~L}^{-1}$ from potato processing wastewater resulted in increased specific biogas production by $0.740 \mathrm{~m}^{3} \mathrm{~L}^{-1}$ of glycerol added (about 1.5 times from the control). High COD removal efficiencies (around 85\%) were obtained. In addition, the study showed that the percentage production of methane decreases with the decrease in purity of the glycerol.

Sulaiman et al. (2009) carried out a study to evaluate the feasibility of adding crude glycerol to anaerobic digesters treating palm oil (Elaeis guineensis Jacq.) mill effluent. At $1.0 \%$ of crude glycerol added, both COD removal efficiency and the methane production rate showed satisfactory results with higher than $90 \%$ and $505 \mathrm{~m}^{3} \mathrm{~d}^{-1}$, respectively. However, once the percentage was increased to a maximum of $5.25 \%$, COD removal efficiency remains high, but the methane production rate decreased significantly to $307 \mathrm{~m}^{3} \mathrm{~d}^{-1}$.

Álvarez et al. (2010) performed a laboratory-scale experiment to maximize methane production by anaerobic co-digestion of three agroindustrial wastes: crude glycerol, swine manure, and tuna fish waste. Experiments were carried out using batch reactors (discontinuous) of $0.5 \mathrm{~L}$ operated under a mesophilic temperature of 35 ${ }^{\circ} \mathrm{C}$. Mixtures of different substrates were introduced into the reactors. A linear programming optimization method was used in order to find the most suitable ratios of cosubstrates that would achieve the highest biodegradation potential and highest methane production rate. The highest biodegradation potential (methane production of 0.321 $\mathrm{m}^{3} \mathrm{~kg}^{-1} \mathrm{COD}$ ) was obtained in the mixture of $84 \%$ swine manure, $5 \%$ fish waste, and $11 \%$ biodiesel waste. On the other hand, the highest methane production rate $(16.4 \mathrm{~L}$ $\mathrm{kg}^{-1} \mathrm{~d}^{-1} \mathrm{COD}$ ) was reached in the mixture containing $88 \%$ swine manure, $4 \%$ fish waste, and $8 \%$ biodiesel waste.

A positive effect of glycerol as a co-fermentation medium is supported by Kacprzak et al. (2009). They determined the optimal combination of corn (Zea mays L.) silage, whey and glycerol in order to obtain maximum productivity of methane rich biogas. The substrates were co-digested in a semi-continuous mode in a $25 \mathrm{~L}$ mesophically operated bioreactor. The methane content of the biogas was steadily increased and reached the highest concentration of 60 to $62 \%$ when the optimum substrate combination was fed to the bioreactor. The biogas production rate was successfully increased from $1.43 \mathrm{~L}$ to $1.82 \mathrm{~L} \mathrm{~L}^{-1} \mathrm{~d}^{-1}$ in the experiment with corn silage and whey when the three substrates of corn silage, whey and the glycerin fraction were digested. The daily amount of biogas produced increased from 33 to $55 \mathrm{~L}$. For the optimum two-substrate combination and process conditions, COD reduction was $16 \%$, which was doubled in co-digestion with the third substrate. A significant increase in biogas yields was also observed.

Fountoulakis et al. (2010) evaluated the feasibility of adding crude glycerol to the anaerobic digesters treating sewage sludge in wastewater treatment plants. Results from this study showed that adding glycerol can increase biogas yields if it does not exceed $1 \%(\mathrm{v} / \mathrm{v})$ concentration in the feed. They found that any further increase of glycerol causes a high imbalance in the anaerobic digestion process.

The results indicate that glycerol, up to $3 \%$, can be advantageously applied as an effective co-substrate to enhance power generation from biogas. However, the process can become unstable and a strict $\mathrm{pH}$ control may be required to avoid inhibition. A similar study was performed by Siles et al. (2010), in which wastewater derived from biodiesel manufacturing was co-digested with glycerol. Wastewater was subjected to an electrocoagulation process in order to reduce its oil content. After mixing, the anaerobic revalorization of the wastewater was studied, employing inoculum-substrate ratios ranging from 5.02 to $1.48 \mathrm{~g}$ volatile suspended solids (VSS) $\mathrm{g}^{-1}$ COD and organic loading rates of 0.27 to $0.36 \mathrm{~g} \mathrm{COD} \mathrm{g}^{-1}$ $\mathrm{VSS} \mathrm{d}^{-1}$. Biodegradability was found to be around $100 \%$, while the methane yield coefficient was $310 \mathrm{~mL} \mathrm{CH}_{4} \mathrm{~g}^{-1}$ COD removed. The results showed that anaerobic codigestion reduces clean water and nutrient requirements, with consequent economic and environmental benefits. These results are an important contribution to adequately managing and revalorizing two byproducts generated during the biodiesel manufacturing process.

Long-term operation of anaerobic digesters for cofermentation of maize silage and crude glycerol was studied by Spalková et al. (2009). Maize silage and a mixture of maize silage with crude glycerol were co-digested under mesophilic conditions in $6 \mathrm{~L}$ laboratory reactors. Biogas production and sludge water quality were similar in the two reactors. The maximum portion of crude glycerol phase added formed $41.5 \%$ of the total daily COD dose (together with maize silage). The researchers found that the maize silage and crude glycerol phase had similar specific biogas outputs per unit quantity of COD. In another work, Hutnan et al. (2009) evaluated the co-digestion of maize silage with glycerol in a large-scale biogas plant. The specific production of biogas from crude glycerol was about 0.890 $\mathrm{m}^{3} \mathrm{~kg}^{-1}$ crude glycerol added. The crude glycerol added, which represented only $5.2 \%$ of overall dose to biogas plant, produced almost $15 \%$ of the overall biogas output. This study demonstrated the positive economic balance of using this co-substrate in biogas plants.

\section{Inhibition of anaerobic co-digestion of glycerol}

The microorganisms involved in anaerobic digestion differ widely in terms of physiology, nutritional needs, growth kinetics, and sensitivity to environmental 
conditions. Failure to maintain the balance between these groups of microorganisms is the primary cause of reactor instability (Demirel and Yenigün, 2002). Inhibition is usually indicated by a decrease in the steady-state rate of methane gas production and the accumulation of organic acids (Kroeker et al., 1979).

Inhibitory substances present in crude glycerol are often the leading cause of anaerobic reactor failure. The metabolism of the anaerobic microorganisms may be negatively affected by the high salinity of crude glycerol phase (Hutnan et al., 2009). The relatively high content of $\mathrm{Na}$ or $\mathrm{K}$ salts originates from the catalyst used for the biodiesel production. Higher concentrations of $\mathrm{Na}$ in the anaerobic reactor can seriously inhibit microbial activity (Chen et al., 2008).

The concentration of Na exceeding $10 \mathrm{~g} \mathrm{~L}^{-1}$ is considered that strongly inhibit methanogenesis (Lefebvre and Moletta, 2006). However, some studies have shown that some highly saline effluents can be treated by anaerobic digestion if a suitable adaptation strategy to methanogenic microorganisms is applied (Soto et al., 1991; Omil et al., 1996). Furthermore, the toxicity of Na depends on several factors, such as the type of substrate under digestion, the antagonistic or synergistic effects of other ions, the nature and the progressive adaptation of microorganisms to high salinity, and the reactor configuration (Chen et al., 2008). The influence and interaction of these factors determine the results reported in different studies. Some experiments have shown a decrease in methane production by $50 \%$ at $\mathrm{Na}$ concentrations in the range of 5.6 to $53 \mathrm{~g} \mathrm{~L}^{-1}$ (Soto et al., 1993; Chen et al., 2008). Other studies have reported inhibition of methane production (up to $10 \%$ ) by $\mathrm{Na}$ at much lower concentrations, in the range of 0.9 to $8 \mathrm{~g} \mathrm{~L}^{-1}$ (Liu and Boone, 1991).

The acclimation of methanogens to high concentrations of $\mathrm{Na}$ over prolonged periods of time has been shown to increase tolerance and shorten the lag phase before methane production begins (Chen et al., 2008). Acclimation includes the gradual increase of salt concentrations in the sludge by low organic loading, providing appropriate conditions for methanogens to adapt to higher salinity (Sleator and Hill, 2002). Hence, the startup period of methanogenesis may take several months. In contrast to the issues raised by these authors, Gebauer (2004) suggests that proliferation in high Na media is more likely to occur as a result of the selection of tolerant species than because of adaptation of every microorganism.

Another limiting factor in the anaerobic digestion process of crude glycerol is the concentration of nitrogen. Nitrogen is an essential nutrient for microorganisms, therefore ammonium concentration up to $200 \mathrm{mg} \mathrm{L}^{-1}$ in the anaerobic reactor is considered to be beneficial (Chen et al., 2008). Glycerol has very low $\mathrm{N}$ content; therefore it is necessary to adjust the $\mathrm{C}: \mathrm{N}$ ratio by co-digestion with an $\mathrm{N}$-rich substrate. Additionally, $\mathrm{N}$ can be added to the reactor in the form of urea.

\section{Use of digestates as soil organic amendment}

A waste material (digestate) is also produced in the anaerobic digestion process. The composition of the digestate depends on the characteristics of the wastes used for anaerobic digestion, but it can include a mixture of water, partially degraded organic matter (solid polymers and short-chain molecules as intermediate degradation products and microorganisms) and inorganic compounds. The recycling of digestates produced during anaerobic digestion for biogas production should be a priority for ensuring the environmental viability of anaerobic digestion processes. This waste can be used as a fertilizer and soil amendment for agricultural and degraded soils. However, the presence of easily-degradable organic matter at a high concentration in digestates can lead to a major increase in soil microbial activity and cause detrimental effects on the plant-soil system, such as phytotoxicity (toxic intermediate degradation products), anaerobic soil conditions, etc. Soil amendment with digestate must guarantee both agricultural and environmental benefits, optimizing the organic matter balance in soil and increasing soil fertility in the long-term (Thuriès et al., 2001). Therefore, the information gained from studies in digestate-treated soil can be very useful to assess the stability of the digestate and help in choosing the most appropriate application. Alburquerque et al. (2010) evaluated the $\mathrm{C}$ and $\mathrm{N}$ mineralization dynamics in a shortterm laboratory study for an agricultural soil amended with some digestates produced from anaerobic codigestion of cattle slurry $+4 \%$ glycerol and cattle slurry $+6 \%$ glycerol. These digestates showed a high organic load and low degree of stability. This fact conditioned the $\mathrm{N}$ and $\mathrm{C}$ mineralization processes, leading to high $\mathrm{CO}_{2}$ production and $\mathrm{N}$-immobilization/denitrification. The authors recommended a further stabilization process, such as the exhaustion of the easily degradable organic matter in order to obtain maximum agricultural and environmental benefits.

\section{CONCLUSIONS}

Residual glycerol from biodiesel production provides a valuable feedstock for biogas generation and has a great potential as a co-substrate to enhance anaerobic digestion of several organic residues, such as corn maize, maize silage, swine and cattle manure, municipal solid wastes, and mixtures of wastewater from olive mills, slaughterhouses, and potato processing. The research findings show that glycerol does not constitute a suitable substrate to obtain high yields of biogas when it is used alone. However, when it is digested with proper mixtures of co-substrates, biogas production is optimized. The feasibility and performance of anaerobic co-digestion of glycerol with other organic waste materials has been studied to various extents. Washing water from biodiesel purification is also a promising material for anaerobic 
degradation, considering the high content of readily degradable organic substances. However, the potential of biogas generation has not been sufficiently studied.

The specific inhibition effects resulting from the substrates composition have to be considered in the anaerobic treatment of biodiesel by-products. In the case of anaerobic digestion of crude glycerol, the high salinity of the substrates may negatively affect methanogenic microorganisms. Since $\mathrm{N}$ is an essential nutrient for microorganisms, the low concentration in crude glycerol and washing water has to be compensated for by ammonium supplements.

Although research has found that there are some industrial plants that use this type of waste as a cosubstrate, studies on this subject are still scarce. The potential of glycerol as a source of energy rather than as waste seems a convenient way of lowering the cost of biodiesel production and making it more competitive.

The incorporation of digestates from glycerol codigestion to soils constitutes an important source of organic matter and nutrients for plants. However, the potential of these digestates as an organic soil amendment has not been sufficiently studied.

\section{ACKNOWLEDGEMENTS}

The authors thank the National Commission for Scientific and Technological Research (CONICYT-Chile) for their financial support (FONDEF Project $N^{\circ}$ D07/1008 and FONDECYT Project N 11085043).

\section{Glicerol residual de la producción de biodiesel,} residuo o potencial fuente de energía: una revisión. Esta revisión proporciona un resumen de la investigación realizada sobre el uso de glicerol crudo, principal subproducto de la industria del biodiesel, como sustrato para la co-digestión anaerobia y producción de biogas. En general, por cada $100 \mathrm{~kg}$ de biodiesel producido, se generan aproximadamente $10 \mathrm{~kg}$ de glicerol. Debido al alto costo de purificación del glicerol para ser utilizado en la industria de alimentos, farmacéutica o cosmética, los productores de biodiesel deben encontrar métodos alternativos de disposición. Varios estudios han demostrado que el uso de glicerol como fuente de $\mathrm{C}$ para la fermentación y generación de biogas es una alternativa prometedora para este residuo. El alto contenido de $\mathrm{C}$ del glicerol aumenta la relación C:N en la mezcla, evitando la inhibición del proceso por exceso de $\mathrm{N}$, incrementando la producción de metano en los digestores entre 50 a $200 \%$. La co-digestión anaeróbica del glicerol y una variedad de biomasa residual puede ser una solución integrada para gestionar estos residuos y producir una fuente de bioenergía amigable con el medioambiente. Por otra parte, el tratamiento anaeróbico del glicerol genera un residuo sólido rico en materia orgánica (bioabono). La incorporación del bioabono al suelo constituye una importante fuente de nutrientes y materia orgánica para las plantas. Sin embargo, el potencial de estos bioabonos como acondicionadores de suelos no ha sido suficientemente estudiado. La utilización del glicerol como potencial fuente de energía se presenta como una forma adecuada para bajar los costos de producción del biodiesel y hacer más competitiva a esta industria emergente.

Palabras clave: co-digestión anaeróbica, glicerol, biogas, biodiesel, bioabono.

\section{LITERATURE CITED}

Adhikari, S., S. Fernando, and A. Haryanto. 2007. Production of hydrogen by steam reforming of glycerin over alumina-supported metal catalysts. Catalysis Today 129:355-364

Angelidaki, I., and L. Ellegaard. 2003. Co-digestion of manure and organic wastes in centralized biogas plants, status and future trends. Applied Biochemistry and Biotechnology 109:95-105.

Alburquerque, J.A., C. De la Fuente, L. Carrasco, J. Cegarra, and M.P. Bernal. 2010. Carbon and nitrogen mineralization in soil amended with digestates from anaerobic codigestion processes. Proceedings of the $14^{\text {th }}$ Ramiran International Conference "Treatment and use of organic residues in agriculture: Challenges and opportunities towards sustainable management", Lisbon, Portugal. 12-15 September. Technical University of Lisbon, Instituto Superior de Agronomia, Lisbon, Portugal.

Álvarez, J.A., L. Otero, and J.M. Lema. 2010. A methodology for optimising feed composition for anaerobic co-digestion of agroindustrial wastes. Bioresource Technology 101:1153-1158.

Amon, T., B. Amon, V. Kryvoruchko, V. Bodiroza, E. Pötsch, and W. Zollitsch. 2006. Optimising methane yield from anaerobic digestion of manure: effects of dairy systems and of glycerine supplementation. International Congress Series 1293:217-220.

Chen, Y., J.J. Cheng, and K.S. Creamer. 2008. Inhibition of anaerobic digestion process: a review. Bioresource Technology 99:40444064.

Chen, H., B. Peng, D. Wang, and J. Wang. 2007. Biodiesel production by the transesterification of cottonseed oil by solid acid catalyst. Frontiers of Chemical Engineering in China 1:11-15.

Da Silva, G.P., M. Mack, and J. Contiero. 2009. Glycerol: a promising and abundant carbon source for industrial microbiology. Biotechnology Advances 27:30-39.

Demirel, B., and O. Yenigün. 2002. Two-phase anaerobic digestion processes: a review. Journal of Chemical Technology and Biotechnology 77:743-755.

Du, W., Y. Xu, and D. Liu. 2003. Lipase-catalysed transesterification of soya bean oil for biodiesel production during continuous batch operation. Biotechnology and Applied Biochemistry 38:103-106.

Ferreira, L., E. Duarte, C. Silva, and M. Malfeito. 2007. Fruit wastes bioconversion for anaerobic co-digestion with pig manure. Process development for the recycling in decentralised farm scale plants. p. 135-140. In Proceedings of the International Conference Progress in Biogas, Stuttgart, Germany.

Fountoulakis, M.S., I. Petousi, and T. Manios. 2010. Co-digestion of sewage sludge with glycerol to boost biogas production. Waste Management 30:1849-1853

Gebauer, R. 2004. Mesophilic anaerobic treatment of sludge from saline fish farm effluents with biogas production. Bioresource Technology 93:155-167.

Gottschalk, G. 1986. Bacterial fermentations. p. 208-282. In Bacterial metabolism. Springer-Verlag, New York, USA.

H'ajek, M., and F. Skopal. 2010. Treatment of glycerol phase formed by biodiesel production. Bioresource Technology 101:3242-3245.

Holm-Nielsen, J.B., C.J. Lomborg, P. Oleskowicz-Popiel, and K.H Esbensen. 2007. Online near infrared monitoring of glycerolboosted anaerobic digestion processes: evaluation of process analytical technologies. Biotechnology and Bioengineering 
99:302-313.

Hutnan, M., N. Kolesárová, I. Bodík, V. Špalková, and M. Lazor. 2009. Possibilities of anaerobic treatment of crude glycerol from biodiesel production. Proceedings of 36th International Conference of Slovak Society of Chemical Engineering, Tatranské Matliare. 25-29 May. Slovak Society of Chemical Engineering, Institute of Chemical and Environmental Engineering, Slovak University of Technology, Bratislava, Slovak Republic.

Kacprzak, A., L. Krzystek, and S. Ledakowicz. 2009. Anaerobic co-digestion of agricultural products and industrial wastes. Environment Protection Engineering 35:215-224.

Kizılkaya, R., and B. Bayraklı. 2005. Effects of N-enriched sewage sludge on soil enzyme activities. Applied Soil Ecology 30:192202.

Kocsisová T., and J. Cvengos. 2006. G-phase from methyl ester production-splitting and refining. Petroleum and Coal 48:1-5.

Kroeker, E.J., D.D. Schulte, A.B. Sparling, and H.M. Lapp. 1979. Anaerobic treatment process stability. Journal of the Water Pollution Control Federation 51:718-727.

Lefebvre, O., and R. Moletta. 2006. Treatment of organic pollution in industrial saline wastewater: a literature review. Water Research 40:3671-3682.

Liu, Y., and D.R. Boone. 1991. Effects of salinity on methanogenic decomposition. Bioresource Technology 35:271-273.

López, J., M. Santos, A. Pérez, and A. Martín. 2009. Anaerobic digestion of glycerol derived from biodiesel manufacturing. Bioresource Technology 100:5609-5615.

Luo, N., X. Fu, F. Cao, T. Xiao, and P.P. Edwards. 2008. Glycerol aqueous phase reforming for hydrogen generation over $\mathrm{Pt}$ catalyst-effect of catalyst composition and reaction conditions. Fuel 87:3483-3489.

Ma, J., M. Van Wambeke, M. Carballa, and W. Verstraete. 2008. Improvement of the anaerobic treatment of potato processing wastewater in a UASB reactor by co-digestion with glycerol. Biotechnology Letters 30:861-867.

Mackay, N., and C. Rowlands. 2008. Anaerobic digestion of biodiesel waste streams for solid energy NZ Ltd. ENNR429 Final Year Research Report. University of Canterbury, Department of Civil and Natural Resources Engineering, Christchurch, New Zealand. Available at http://www.civil.canterbury.ac.nz/cochrane/ NREProjects/Group8_2008.pdf (accessed 19 April 2010).

Mladenovska, Z., S. Dabrowski, and B.K. Ahring. 2003. Anaerobic digestion of manure and mixture of manure with lipids: biogas reactor performance and microbial community analysis. Water Science and Technology 48:271-278.

Omil, F., R. Mendez, and J.M. Lema. 1996. Anaerobic treatment of seafood processing waste waters in an industrial anaerobic pilot plant. Water SA 22:173-181.

Pachauri, N., and B. He. 2006. Value added utilization of crude glycerol from biodiesel production: a survey of current research activities. In Proceedings of the ASABE Annual International Meeting, Portland, Oregon. 9-12 July. American Society of Agricultural and Biological Engineers (ASABE), St. Joseph, Missouri, USA.

Pyle, D. 2008. Use of biodiesel-derived crude glycerol for the production of omega-3 polyunsaturated fatty acids by the microalga Schizochytrium limacinum. Master on Sciences Thesis in Biological Systems Engineering, Virginia State University, Blacksburg, Virginia, USA.

Rahmat, N., A.Z. Abdullah, and A.R. Mohamed. 2010. Recent progress on innovative and potential technologies for glycerol transformation into fuel additives: a critical review. Renewable and Sustainable Energy Reviews 14:987-1000.

Raven, R.P.J.M., and K.H. Gregersen. 2007. Biogas plants in Denmark: successes and setbacks. Renewable and Sustainable Energy Reviews 11:116-132.
Schievano, A., G. D’Imporzano, and F. Adani. 2009. Substituting energy crops with organic wastes and agro-industrial residues for biogas production. Journal of Environmental Management 90:2537-2541

Siles, J.A., M.A. Martín, A.F. Chica, and A. Martín. 2010. Anaerobic co-digestion of glycerol and wastewater derived from biodiesel manufacturing. Bioresource Technology 101:6315-6321.

Sleator, RD., and C. Hill. 2002. Bacterial osmoadaptation: the role of osmolytes in bacterial stress and virulence. FEMS Microbiology Reviews 26:49-71.

Slinn, M., K. Kendall, C. Mallon, and J. Andrews. 2008. Steam reforming of biodiesel by-product to make renewable hydrogen. Bioresource Technology 99:5851-5858.

Soldano, M., C. Fabbri, and S. Piccinini. 2007. Co-digestion plant in dairy cattle farm in Emilia Romagna region (Italy). p. 95-99. In Proceedings of the International Conference Progress in Biogas, Stuttgart, Germany. 19-21 September. International Biogas and Bioenergy Centre of Competence (IBBK), Kirchberg/Jagst, Germany.

Solomos, B., A.P. Zeng, H. Biebl, H. Schlieker, C. Posten, and W.D. Deckwer. 1995. Comparison of the energetic efficiencies of hydrogen and oxochemicals formation in Klebsiella pneumoniae and Clostridium butyricum during anaerobic growth on glycerol. Journal of Biotechnology 39:107-117.

Soto, M., R. Mendez, and J.M. Lema. 1991. Biodegradability and toxicity in the anaerobic treatment of fish canning wastewaters. Environmental Technology 12:669-677.

Soto, M., R. Mendez, and J.M. Lema. 1993. Sodium inhibition and sulphate reduction in the anaerobic treatment of mussel processing wastewaters. Journal of Chemical Technology and Biotechnology $58: 1-7$

Spalková, V., M. Hutnan, and N. Kolesárová. 2009. Selected problems of anaerobic treatment of maize silage," in Proceedings of 36th International Conference of Slovak Society of Chemical Engineering, Tatranské Matliare. 25-29 May. Slovak Society of Chemical Engineering, Institute of Chemical and Environmental Engineering, Slovak University of Technology, Bratislava, Slovak Republic.

Sulaiman, A., M.R. Zakaria, M.A. Hassan, Y. Shirai, and Z. Busu. 2009. Co-digestion of palm oil mill effluent and refined glycerin wash water for chemical oxygen demand removal and methane production. American Journal of Environmental Sciences 5:639646.

Suppes, G.J. 2006. Biobased propylene glycol and monomers from natural glycerin. EPA. Available at http://epa.gov/greenchemistry/ pubs/pgcc/winners/aa06.html (accessed 23 March 2011).

Thompson, J.C., and B.B. He. 2006. Characterization of crude glycerol from biodiesel production from multiple feedstocks. Applied Engineering in Agriculture 22:261-265.

Thuriès, L., M. Pansu, C. Feller, P. Herrmann, and J.C. Rémy. 2001. Kinetics of added organic matter decomposition in a Mediterranean sandy soil. Soil Biology and Biochemistry 33:9971010.

Valliyappan, T., T.T. Bakhshi, and A.K. Dalai. 2008. Pyrolysis of glycerol for the production of hydrogen or syn gas. Bioresource Technology 99:4476-4483.

Weiland, P. 2000. Anaerobic waste digestion in Germany - status and recent developments. Biodegradation 11:415-421.

Yang, Y., K. Tsukahara, and S. Sawayama. 2008. Biodegradation and methane production from glycerol-containing synthetic wastes with fixed-bed bioreactor under mesophilic and thermophilic anaerobic conditions. Process Biochemistry 43:362-367.

Yazdani, S.S., and R. Gonzalez. 2007. Anaerobic fermentation of glycerol: a path to economic viability for the biofuels industry. Current Opinion in Biotechnology 18:213-219. 